\title{
Anatomical and Morphometric Study of Small and Large Intestine of Bali Cattle
}

\section{Luh Gde Sri Surya Heryani ${ }^{1}$, Ni Nyoman Werdi Susari ${ }^{2}$, Luh Putu Syamadina Pramesya Nareswari ${ }^{3}$}

\author{
${ }^{1}$ Veterinary Anatomy Laboratory, Faculty of Veterinary Medicine, \\ Udayana University,Bali, Indonesia \\ Email: surya_heryani@unud.ac.id \\ ${ }^{2}$ Veterinary Anatomy Laboratory, Faculty of Veterinary Medicine, \\ Udayana University,Bali, Indonesia \\ Email: nwsusari@unud.ac.id \\ ${ }^{3}$ Student of Faculty of Veterinary Medicine \\ Udayana University,Bali, Indonesia \\ Email: syamanareswari@gmail.com
}

Corresponding Author: surya_heryani@unud.ac.id

\begin{abstract}
Information on the anatomical and morphometric structure of the digestive system of Bali cattle will provide a clear and precise picture if abnormalities occur in the organs in the digestive system. This study aims to determine the anatomical and morphometric structures of the small intestine and large intestine of Bali cattle. Samples were taken from 14 Bali cattle and based on gross pathology examination declared healthy. The results showed that the average length of the small intestine including the duodenum, jejunum and ileum are $473.07 \mathrm{~cm}, 529.64 \mathrm{~cm}$, and $363.64 \mathrm{~cm}$; and successive widths are $5.50 \mathrm{~cm}, 6.00 \mathrm{~cm}$, and 6.11 $\mathrm{cm}$. While the average length of the large intestine which includes the cecum, colon and rectum are $36.78 \mathrm{~cm}, 371.21,50.00 \mathrm{~cm}$; while the width are $9.65 \mathrm{~cm}, 11.47 \mathrm{~cm}$, and $8.85 \mathrm{~cm}$. Jejunum has the longest size in the small intestine, while in the large intestine the longest size is the colon. The right information and data about the digestive system are very important and useful to support further clinical and preclinical research, and the results of this study can be used as a reference in determining the characterization of Bali cattle.
\end{abstract}

\section{Keywords: Anatomy, Morphometrics, Bali cattle, Large intestine, Small intestine.}

\section{I.INTRODUCTION}

Cattle is one of the food sources, especially meat. Growth and productivity are important and must be considered. The digestive system is one of the factors that play a role in cow growth. Diseases that often occur in cows are diseases associated with the digestive system. Many diseases are related to the digestive system.
Bali cattle are native cows with a fairly large population and a wide distribution in Indonesia. Diwyanto and Priyantini [1] stated that Bali cattle are native Indonesian beef cattle and are recognized as superior breeds because they have a high fertility and conception rate of $85.9 \%$ and the percentage of calf $70-81 \%$ [2], high reproductive potential, high carcass weight, quickly fattened. Bali 
cattle also easily adapted to the new environment, so it is known as pioneering cows [3].

Another advantage that possessed by Bali Cattle is a good calving interval, which is one calf per year. The same thing was also reported by Siregar [4], that Bali cows have an advantage compared to other local cows because they have high fertility, pregnancy rate and high birth rate (more than $80 \%$ ) and potential as meat sources.

The higher import of beef and cattle to meet domestic demands and the higher public awareness of the importance of nutrition, especially those derived from animal protein, causes the demand for livestock products, especially meat, increase. It can be a force for the government to improve domestic cattle productivity by managing the native Indonesian cattle as well as possible [2], this is in accordance with the government's program to increase food self-sufficiency, especially beef, that declared in 2014 .

The digestive tract is an organ that plays an important role in converting feed given to cattle into meat products. The amount of meat bone ratio (without fat) and meat bone ratio (with fat) is the result of the digestion process of feed in a cow's body [5].

The digestive system (tractus digestivus) consists of a membranous muscular tube extending from the mouth to the anus. Its function is to food enter, grind, digest and absorb food and remove solid waste. The digestive system converts nutrients in food into simpler compounds that can be absorbed and used as energy, build other compounds for metabolic purposes. Digestion is a series of processes that occur in the digestive tract to allow absorption [5].

Most of the digestion and absorption of nutrients occurs in the small intestine. The digestive process is assisted by intestinal glands that produce mucin which functions as a lubricant and sucrase enzyme that breaks sucrose into glucose, and fructose; maltase breaks down maltose into glucose; trypsin breaks down intermediate forms of protein into amino acids [6].

Nuswantara [7] states the process of final digestion occurs in the intestine, meaning that all substances that are still double molecular or still in a long chain will be broken down to become more simple substances that are generally single molecules. This new substance will be absorbed in the intestine.

The capacity of the digestive tract of cattle needs to be known so that the management of feeding can be done appropriately. The size and shape of the digestive tract affect the capacity of the feed that can be absorbed. Several studies have been carried out regarding the 
histological description of the intestines [8] and stomach [9] of Bali cattle. Still, information about the shape and size of cattle intestines, especially in Bali cattle, can be said to be missing. Information obtained from this research will be the basis for preserving and developing Bali cattle as beef cattle that can meet food needs in Indonesia. Data, information, and good knowledge about the digestive system is fundamental to know and become a basis for use in clinical, preclinical, and identification research on the possibility of abnormalities in the digestive system organs and other pathological conditions in Bali cattle. Until now, the scientific data about how the anatomy form, such as shape and size of the digestive system, especially the small intestine and large intestine of cattle, has not been reported. Considering that Bali cattle is one of the germplasms and biodiversity of Indonesia, studies to reveal matters related to these animals are very important to do.

\section{MATERIAL AND METHODS}

Samples of the digestive tract were collected from the slaughtered adult Bali cattle, wich qualified to slaughter, at the slaughterhouse (RPH) Mambal, Badung, Bali. Morphometric measurements in the form of length and width of the digestive tract measured in several parts then accumulated and averaged. The tools used in this study consisted of scalpels, scissors, tweezers, and to measure the size of each organ of the digestive tract using a measuring instrument brand Butterfly with an accuracy of $0.01 \mathrm{~cm}$ and a sliding term Etherna brand with a precision of $0.01 \mathrm{~cm}$. Measurements were made at the Laboratory of Veterinary Anatomy, Faculty of Veterinary Medicine, Udayana University in Denpasar. The study was conducted from June to October 2019. The data collected in the form of primary data from observations and measurements of the anatomical structure of the digestive tract of males and females Bali cattle. Measurement data were analyzed statistically by descriptive analysis, normality test and homogeneity test for the collected data [10].

\section{RESULT}

The results of the anatomical structure of the small intestine and large intestine, which includes the duodenum is curved in shape like a horse's hoof. The pancreas is located in the arch. On the right side of the duodenum are the common bile duct (ductus choledochus) and pancreatic duct. The jejunum is curvaceous and is located on the upper left of the intestine minor, with the mediation of the fan-shaped 
peritoneum (mesenterium) allowing entry and exit of superior mesenteric arteries and space between the layers of the peritoneum. veins, lymph vessels, and nerves to the

Table 1. Minimum, Maximum and Mean \pm Standard deviations of Morphometric Measurements of Bali Cattle Small Intestine.

\begin{tabular}{|c|c|c|c|c|}
\hline No & $\begin{array}{l}\text { Samples } \\
(\mathrm{n}=14)\end{array}$ & Minimum $(\mathrm{cm})$ & Maximum $(\mathrm{cm})$ & Mean \pm SD \\
\hline 1. & $\begin{array}{l}\text { Duodenum } \\
\text { Length } \\
\text { Width } \\
\end{array}$ & $\begin{array}{c}467.00 \\
5.00 \\
\end{array}$ & $\begin{array}{c}479.00 \\
6.00 \\
\end{array}$ & $\begin{array}{c}473.07 \pm 4.84 \\
5.50 \pm 0.37\end{array}$ \\
\hline 2. & $\begin{array}{l}\text { Jejunum } \\
\text { Length } \\
\text { Width }\end{array}$ & $\begin{array}{c}505.00 \\
5.60\end{array}$ & $\begin{array}{c}540.00 \\
6.40\end{array}$ & $\begin{array}{c}529.64 \pm 10.46 \\
6.00 \pm 0.21\end{array}$ \\
\hline 3 & $\begin{array}{l}\text { Ileum } \\
\text { Length } \\
\text { Width }\end{array}$ & $\begin{array}{c}354.00 \\
5.70\end{array}$ & $\begin{array}{c}374.00 \\
6.50\end{array}$ & $\begin{array}{c}363.64 \pm 5.59 \\
6.11 \pm 0.33\end{array}$ \\
\hline
\end{tabular}

Table 2. Minimum, Maximum and Mean \pm Standard deviations of Morphometric Measurements of Bali Cattle Large Intestine.

\begin{tabular}{llccc}
\hline No & $\begin{array}{l}\text { Samples } \\
(\mathrm{n}=14)\end{array}$ & Minimum $(\mathrm{cm})$ & Maximum $(\mathrm{cm})$ & Mean \pm SD \\
\hline 1. & Caecum & & & \\
& Length & 35.00 & 39.00 & $36.78 \pm 1.33$ \\
& Width & 9,40 & 10.20 & $9.65 \pm 0.25$ \\
\hline 2. & Colon & & & \\
& Length & 365.00 & 379.00 & $371.21 \pm 4.95$ \\
& Width & 10.90 & 12.00 & $11.47 \pm 0.41$ \\
\hline 3 & Rectum & & & \\
& Length & 46.50 & 53.00 & $50.00 \pm 2.18$ \\
& Width & 8.60 & 9.10 & $8.85 \pm 0.16$ \\
\hline
\end{tabular}

The cross-section of jejunum is wider than duodenum, the walls are thicker, and contain many blood vessels. Ileum: the borderline between the ileum and jejunum is unclear. The ileum is the small intestine which is located right below connected to the cecum. The cecum is a closed pouch located below the area of the appendix ileocecal valve. In the cecum, there is an ileocecal valve and appendix attached to the end of the cecum. The vermiform appendix, a narrow dead-end tube containing lymphoid tissue, protrudes from the tip of the cecum. The colon is part of the large intestine from the cecum to the rectum. The colon has three parts. The rectum is the last part of the digestive tract. The rectum ends at the anal canal and opens to the exterior in the anus. 


\section{DISCUSSION}

The digestive tract consists of cavum oris, esophagus, gastric, intestinum tenue, intestinum crassum, and anus. All organs of the digestive tract anatomically have different shapes and sizes depending on the species, age, and eating behavior. Digestion is the process of physical and chemical changes of food into smaller particles and the decomposition of complex molecules into simpler molecules [11]. Based on the changes of food ingredients in the digestive tract, the digestive process can be divided into three types, namely: mechanical digestion, hydrolytic digestion, and fermentative digestion. Fermentative digestion in ruminants occurs in the rumen or rumen reticulum in the form of changing certain compounds into other compounds that are entirely different from their original molecular substances [12].

The digestive tract is an organ that plays an important role in converting feed given to cattle into meat products [5]. Investments in modern farms designed to maximize productivity and generate profits by increasing carcass size have proven to be an appropriate alternative to improving the production index [13]. Owens and Goetsch [14] state, the ruminant stomach size is related to the type of feed; rumen volume will be greater if the animal feed contains more coarse feed.

The small intestine of Bali cattle is located in the right side of the abdominal cavity, starting at the pylorus and ending in the caecum at the ileocaecal junction. Observations show that it consists of three segments called the duodenum, jejunum and ileum which are connected to the large intestine at the very bottom of the digestive tract which starts with the caecum and ends with the anus. The whole organ is displayed as a muscular and elastic structure along the channel; there is little difference between segments. Anatomically, it was found that the dorsal part of the small intestine related to the abdominal wall and attached along the dorsal mesentery. The mesentery is long and allows an extraordinary level of mobility in the small intestine and is an entry point for blood vessels and nerves, which maintains the position of the small intestine in place [15].

The small intestine becomes a place of digestion and absorption. The mucous membrane has protruding and soft bumps like fingers. Its main function is peristaltic and nutrient absorption [5]. The small intestine consists of three parts, namely duodenum jejunum and ileum. The duodenum has a circular mucosal fold with many villi. Duodenum is similar to the jejunum; the size of the villi is slimmer, 
smaller and more numerous when compared to the jejunum. The ileum region is similar to the jejunum, with villi forming groups. The ileal part does not form folds [16].

The small intestine is a digestive organ that has the function of absorption of food substances. The small intestine consists of 3 parts, namely the duodenum, jejunum and ileum [17]. Digesta that enters the duodenum is mixed with the secretion of the duodenum itself, the liver and pancreas. The duodenal gland produces an alkaline liquid that is useful as a lubricant and protects the duodenal wall from hydrochloric acid $(\mathrm{HCl})$ from abomasum.

The large intestine consists of three parts, namely the cecum, colon, and rectum [18]. The large intestine is histologically composed of tunica mucosa (epithelium, lamina propria, and muscularis mucosae), tunica submucosa (loose connective tissue, blood vessels and nerves), tunica muscularis (circular and longitudinal), and tunica serosa.

The large intestine of Bali cattle is a hollow muscular tube with a length of about $457.99 \mathrm{~cm}$, which extends from the cecum to the anus. The diameter of the large intestine is bigger than the small intestine with an average of about $9.99 \mathrm{~cm}$. But, the closer the anus, much smaller the diameter. The layers of the large intestine from the inside out are the mucous membranes, the elongated muscle layers, and the connective tissue. The size is bigger than the small intestine, the mucosa is softer than the small intestine and has no villi. In the digestion process digesta that enters the large intestine is undigested material in the small intestine. Mucous glands in the large intestine do not release enzymes, digestion that occurs in the large intestine due to the presence of enzymes from the small intestine that is carried along with digesta and the presence of microbial activity. The large intestine has a variety of functions which are all related to the final process of intestinal contents. The most important function of the large intestine is to absorb water and electrolytes, which are almost complete in the right colon. The sigmoid colon functioned as a reservoir that holds the dehydrated faecal mass until the defecation process takes place. From this study, it can be concluded that the larger a livestock, the higher its feed consumption, thereby affecting its rumen capacity. This is consistent with the opinion of Sutardi [12] that the bodyweight of livestock is directly proportional to the level of feed consumption. The higher the body weight, the higher the level of consumption of feed.

The cecum is a dead-end pouch associated with the proximal colon. Cecum 
has a function as a small-scale absorption which is assisted by microbes. The colon delays the flow of indigestible material and then becomes a place of microbial fermentation. Undigested material is removed from the large intestine through the anus. The colon has a function as a massive absorption of VFA and water. The rectum functions as temporary storage of feces before being expelled through the anus. This is in accordance with the opinion of Masyitha [18] that the large intestine in ruminants consists of the cecum, colon and rectum. The caecum of an appendix pocket is associated with the proximal colon at the ileocaecal meeting point. Both the caecum and the proximal colon delay the flow of material that cannot be digested and then become a place for microbial fermentation

So far there have been no other reports that examined the length and width of the small intestine and large intestine of cows, especially Bali cattle. Similar studies on donkeys were carried out by Jerbi et al. [19], reported that the length of the donkey's small intestine varies between 7 to $8 \mathrm{~m}$, while the large intestine's length reaches $4 \mathrm{~m}$. Another study of a similar type was also carried out in horses by Barone [20], which stated that the length of the small intestine of the horse was 12 $\mathrm{m}$, while the length of the large intestine was $8 \mathrm{~m}$, whereas in rabbits studied by
Alves et al. [21] and. Fitri[22] reported that the length of the small intestine of Java cattle is $20.92 \mathrm{~m}$ and that the large intestine is $6.17 \mathrm{~m}$. Species differences between all of these animals cause morphometric size differences. Knowledge of anatomy is very important for clinical examination and diagnosis, especially in acute abdominal pathological conditions, for radiological interpretation, exploratory laparotomy and abdominal cavity surgery.

\section{V.CONCLUSION}

In conclusion, the Bali cattle average length of the small intestine is $1,366.65 \mathrm{~cm}$ and a width of $5.87 \mathrm{~cm}$, while the length of the large intestine is $457.99 \mathrm{~cm}$ and a width of $9.99 \mathrm{~cm}$.

\section{REFFERENCE}

[1] Diwyanto, K dan A. Priyanti, 2006. Kondisi, Potensi dan Permasalahan Agribisnis Peternakan Ruminansia dalam Mendukung Ketahanan Pangan. Prosiding Seminar Nasional. Penerbit BP UNDIP, Semarang. 3 Agustus 2006: 155167

[2] E. Handiwirawan dan Subandriyo. 2004. Potensi dan Keragaman Sumberdaya Genetik Sapi Bali. Lokakarya Nasional SapiPotong

[3] Suardana, I. W., Suarsana, I. N., Sujaya, I. N., \&Wiryawan, K. G. (2007). Isolasi dan identifikasi bakteri asam laktat dari cairan rumen sapi bali sebagai kandidat biopreservatif. Jurnal veteriner, 8 (4), 155-159. 
[4] S. Siregar. 2008. Jenis Sapi Perah, Tehnis Pemeliharaan dan Analisis Usaha

[5] E. Purbowati., E. Rianto, WS. Dilaga, CMS. Lestari dan R. Adiwinarti. 2014. Bobot dan Panjang Saluran Pencernaan Sapi Jawa dan Peranakan Ongole di Brebes. Jurnal Peternakan Indonesia, 16(1).

[6] Yasin. 2010. Pencernaan serat kasar pada ternak unggas. Jurnal Ilmiah Inkoma. 21(3): 227-236.

[7] Nuswantara, Limbang Kustiawan. 2002. Ilmu Makanan Ternak Ruminansia (Sapi Perah). Fakultas Peternakan. UNDIP.

[8] Suwiti, N. K., Setiasih, N. L. E., Suastika, I. P., Piraksa, I. W., \&Susari, N. N. W. (2010). Studi Histologi Usus Besar Sapi Bali. Buletin Veteriner Udayana.

[9] Depari, E. E., Farhani, A., Batan, I. W., \& Kardena, I. M. (2017). Gambaran Histopatologi Rumen dan Retikulum Sapi Bali Akibat Adanya Benda Asing. Jurnal Sain Veteriner, 35(1), 35-41.

[10] Y. M. Goh, 2008. Eperimental Design and Sampel Size Issues in Laboratory Animal Experiments. Departemen if Veterinary Preclinical Sciences, Faculty of Veterinary Medicine. University Putra Malaysia.

[11] Kang, J. (2013). Digestion and absorption. In Nutrition and Metabolism in Sports, Exercise and Health (pp. 124-150). Routledge.

[12] Sutardi. 2012. Landasan Ilmu Nutrisi. Jilid I. Departemen Ilmu Makanan Ternak. Fakultas Peternakan. Institut Pertanian Bogor

[13] E.F.M. Bonilha, Branco RH, Bonilha SFM, Araújo FL, J. N. dos Santos G. Cyrillo, and Magnani E. 2014. Body chemical composition, tissue deposition rates and gain composition of young Nellore cattle selected for postweaning weight. R. Bras. Zootec. vol.43 (4) Viçosa Apr. 2014.

[14] F.N. Owens and A.L. Goetsch. 1993. Ruminal fermentation. In: D.C. Church (Ed.) The Ruminant Animal Digestive Physiology and Nutrition. Pp.145-171, Waveland Press, Inc. Prospect Heights, Illinois.

[15] Bello, Shehu SA, Siraj K, Baraya YS, Garba S and Abdullahi AU. 2019. Morphological Changes of the Small Intestine of Red Sokoto Goat (Capra aegagrushireus): Anatomical View. ACTA SCIENTIFIC MEDICAL SCIENCES. Volume 3 Issue 2 February 2019.

[16] Bacha Jr, W. J., \& Bacha, L. M. (2012). Color atlas of veterinary histology. John Wiley \& Sons.

[17] Frandson, R. D. (1986). Anatomy and physiology of farm animals (No. Ed. 4). Lea \&Febiger.

[18] Masyitha, D., Nazaruddin, N., Gani, F. A., \&Balqis, U. (2019). Studi Histologis Usus Besar Sapi Aceh (Histological Study of Large Intestine of Aceh Cattle). JURNAL ILMIAH MAHASISWA VETERINER, 3(2), 62-70.

[19] Jerbi, H., Rejeb, A., Erdoğan, S., \& Pérez, W. (2014). Anatomical and morphometric study of gastrointestinal tract of donkey (Equus africanus asinus). Journal of Morphological Sciences, 31(01), 018-022.

[20] R. Barone. 1997 Anatomie comparée des mammiféeres domestiques. Splanchnologie I. Appareil digestif, appareil respiratoire. $3 . \quad$ ed. Paris:VigotFréres, 1997.

[21] J.R. Alves, L.R. Lopes and T. Sasasaki. 2014. Morphometric Study in Stomach of Rabbits. Int. J. Morphol. 32(1):227-231 
[22] N. Fitri. 2010. Hubungan antara

berbagai umur. Fakultas bobot badan dengan proporsi organ

Peternakan, Universitas pencernaan Sapi Jawa pada

Diponegoro, Semarang. 